\title{
How grammar can be best taught
}

\author{
Luciana Braga Carneiro Leão*
}

\begin{abstract}
In the field of language teaching, especially in second language teaching, teachers and researchers are constantly concerned with the most efficient ways to provide knowledge to learners leading to acquisition. This article aims to reflect form-focused instructional options regarding grammar teaching, in light of the computational model for second language acquisition, and discuss if there is a best way to teach grammar and what it is. For that, firstly, the instructional possibilities are presented, in their macro and micro-options. Secondly, discussions on whether we should select an option or not and on whether we could balance different options throughout a lesson are carried. Finally, sample material is provided in order to present possible ways to conduct a grammar lesson.

Keywords: Computational model; form-focused instruction; instructional options; pedagogical grammar.

\section{RESUMO}

No campo do ensino de línguas, e em especial no ensino de segunda língua, professores e pesquisadores demonstram constante preocupação com o uso de meios mais eficientes para prover aos aprendizes conhecimento que culminem em aquisição. Os objetivos desse artigo são analisar opções de instrução focada na forma, no que se refere ao ensino de gramática, à luz do modelo computacional de aquisição de segunda língua; e discutir a existência de uma melhor maneira de ensinar gramática e qual seria. Para tal, primeiramente, as possibilidades de instrução são apresentadas, em seus macro e micro desdobramentos. Em seguida, discussões sobre a necessidade de selecionar opções e a possibilidade de combiná-las são conduzidas. Finalmente, um material demonstrativo é fornecido a fim de apresentar maneiras possíveis de se conduzir uma lição de gramática.

Palavras-chave: Modelo computacional; instrução focada na forma; opções instrucionais; gramática pedagógica.
\end{abstract}

\section{Introduction}

Throughout the years in which I have been both an ESL university student and an ESL teacher, for many times I have seen classmates and colleagues saying that they prefer certain option of grammar instruction over the others. Most of the times, they would fiercely defend their choice, pointing out its benefits and the other options' inefficiencies. Usually, it would come together with the "defense" of certain methodology over the others, since the adoption of methodologies is still a reality in the

\footnotetext{
* Mestranda em Estudos de Linguagem pela Universidade Federal Fluminense (UFF), bolsista CNPq e professora I de língua inglesa na Fundação de Apoio à Escola Técnica (FAETEC).
} 
Brazilian English Language Teaching - ELT - scenario even after the post-method era. As for myself, I have never selected one kind of grammar instruction, or one methodology, for I have worked with many different options during my professional formation. Therefore, even working in a language school that adopts one specific methodology, and consequently one specific option of grammar instruction, I have mixed different options in my practice. Still, the feelings of "crime" and "alienation" have always been with me. Crime for I have been working differently from what the institution demands from me, and alienation for feeling labeled as so by my colleagues since I did not have a firm choice among the options.

Yet, in the last few years, as I have gone deeper into ELT studies, I started realizing that my lack of selection was not at all wrong or inadequate of a teacher. In fact, the idea of mixing options in grammar instruction has seemed to me, in both theory and practice, as good as the concept of the post-method era - in which the idea that there is no best method prevails, so it is teachers' aim to systematically observe their teaching, interpret their classroom events, evaluate their outcomes, identify problems, find solutions, and try them out to check what works and what does not (KUMARAVADIVELU, 2003). It is important to point out, though, that a reckless use of different ways of grammar instruction is not defended in this article. It is true that teachers are demanded to make instantaneous decisions on what to teach and how to do it (ELLIS, 1998). But it does not allow them to do so without pondering the effects of their choices on the students' interlanguage development. Instead, what is proposed here is an analysis of context, needs, and students' input and output, and then a selection of what options best fit each situation, separately or together.

Teachers are not just transmitters of knowledge, but creative and context-sensitive problem-solvers (DEWEY, 1933). If a teacher is aware of the options and knows the benefits of each in advance, (a) he can plan his lesson with different options, which enriches it, and (b) when a shift from one option to the other or the association of some of them is necessary during the class, the teacher is capable not only of doing it at the moment it is required so, but also of selecting ways that will enhance his lesson.

Hence, the different possibilities of grammar instruction in ELT are presented and discussed, and after that, possible ways for the ESL teacher to use them in his practice are proposed. 


\section{Instructional options}

As one starts planning a second or foreign language - L2 and FL, respectively course, among many important choices to be made, the first and indispensable one is the one regarding focus (VIDAL, 2007). The three main options are focus-on-form, focuson-meaning and focus-on-use. Among the many existing definitions for these and other labels $^{2}$, the indication pointed out by Spada (1997) seems one of the more interesting and complete. For the author, form-focused instruction would mean "any pedagogical effort which is used to draw the learners' attention to language form either implicitly or explicitly" (p.73). Moreover she conveys that it can indicate "direct teaching of language (e.g. through grammatical rules) and/or reaction to learners' errors (e.g. corrective feedback)."

The first form-focused studies were concerned with whether this type of instruction could get the students to acquire grammar rules or not. Once it proved to be effective, further studies were developed in order to test and indicate which options inside focuson-form instruction were possible and which one would work best. The search for best options inside focus-on-form instruction was a way to analyze things beyond methods and methodologies, which was already seen as a concept "too crude to be used" (KUMARAVADIVELU, 2003).

The best model to basically identify these options is probably the computational model, an information-processing model in which L2 learners are seen as "intelligent machines that process input in a mental black box". This "mental black box" contains previously acquired mechanisms that make it possible to the learner to internalize new knowledge and use it in output tasks (ELLIS, 1998).

\footnotetext{
2 In this article, the terms focus-on-form and form-focused instruction are used interchangeably. On the matter of different labels and whether they intend the same concept or not, see Vidal (2007).
} 


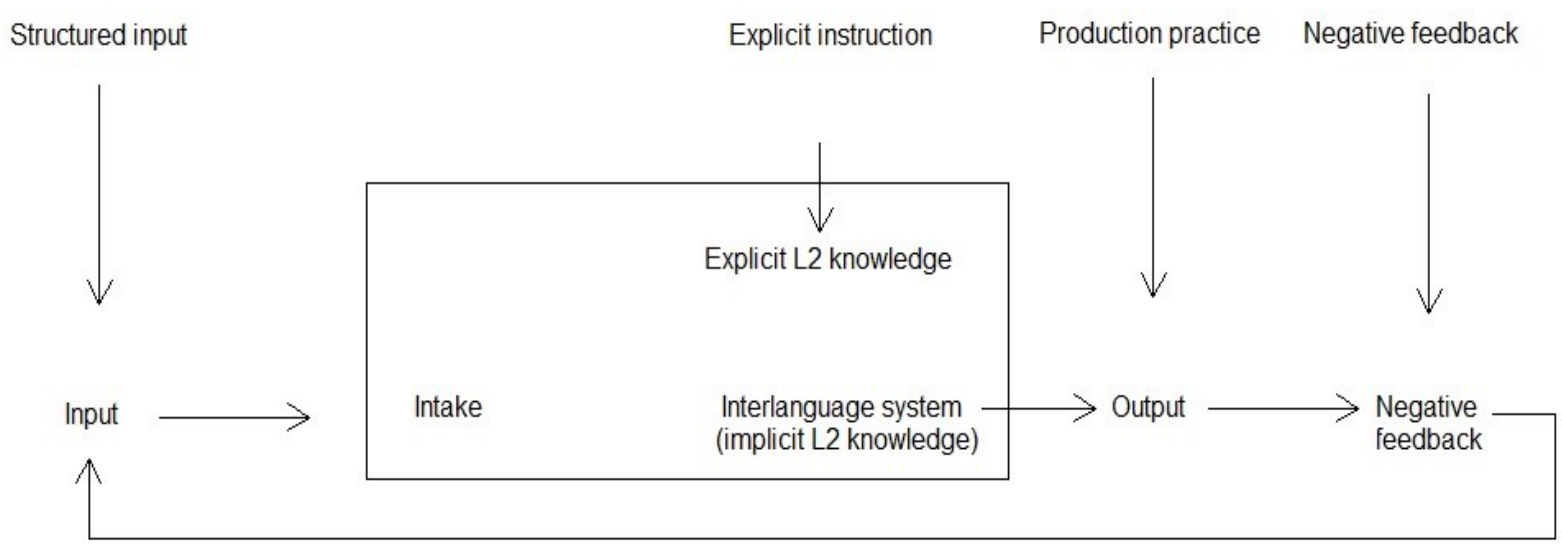

Ellis, 1998: 43

According to this model, form-focused instruction can intervene in interlanguage development in four points. They are structured input, explicit instruction, production practice and negative feedback. Through this process, the learners are exposed to input that is held in the short-term memory, i.e. the intake, and, with the emphasis of the explicit instruction, internalized in the long-term memory, i.e. the knowledge. With production practice tasks, the student can output it, and if a mistake or error is made, he receives feedback, which will be a new form of input.

These instructional options are the ones intended to be discussed and analyzed in this article. But first it is necessary to understand each of them separately and how they treat grammar.

\subsection{Structured Input}

The structured input option is the one where grammar instruction is directed at input. The learners are induced to notice the target grammar point and its features as they try to comprehend oral and written texts. Yet, the students are not supposed to find it all out by themselves within texts presented to them at random. The input is specially contrived to induce comprehension of the target structure, i.e. it addresses to the 
grammar topic, so the learners can process it. Lee and VanPatten (2003) go further into this definition by conveying that it is an "input that is manipulated in particular ways to push learners to become dependent on form and structure to get meaning". For the adopters of the structured input option, acquisition occurs when learners attend to the new structure in input rather than when they try to produce it. Therefore, activities for developing structured input should (a) present one thing at a time, (b) have learners do something with the input and (c) keep learners' processing strategies in mind.

Some ways of doing it are through input enhancement and input flood. Input enhancement is when the learners' attention is drawn to a certain linguistic aspect, by the use of typological resources, such as bold, underlining and italics. Input flood, on the other hand, is when the teacher gives the students lots of input, believing that the more opportunities are given to the learner to notice the new structure, the bigger the possibility that they will use it. Activities within structured input include supplying information, surveys, matching, binary options (e.g. true/false, logical/illogical, normal/strange), ordering or ranking, and selecting alternatives, among others. The learners' responses to the input stimuli are nonverbal or minimally verbal; they do not involve actually producing the structure.

\subsection{Explicit Instruction}

In explicit instruction, the teacher attempts to develop the learners' explicit understanding of grammar rules. For that, there are two major possibilities. They are to teach explicit rules directly - taking the form of oral or written explanations of the grammatical phenomena - or to develop activities that enable the learners to discover the rules for themselves - through consciousness-raising tasks.

Ellis (1998) points out that there are several reasons for favoring the indirect option, such as the motivation generated by making the students discover the rules by themselves, and the use of metalanguage. Yet, many studies (e.g. ROBINSON, 1996; DEKEYSER, 1994, 1995; ELLIS, 1993) point to the outperformance of groups that received direct explicit instruction in comparison to groups that received different types of indirect explicit instruction. However, there are no studies that present clear evidence 
pointing at any kind of explicit instruction as producer of greater grammatical accuracy in communicative language use.

\subsection{Production Practice}

Learning a language, especially an L2 grammar structure, requires time for the students to integrate it into their interlanguage systems. The production practice is the moment, in class, in which opportunities for the learners to practice how to produce a specific structure as they use their understanding of the rule. It is composed by a number of devices for eliciting production of target structures. The aim of the teacher here is to develop automatism, i.e., to push learners from controlled to automatic use of these structures.

This option can be of a controlled or free nature. In the controlled practice, students are provided with tasks such as text manipulation, where texts are already given with blanks that the students have to complete with the correct usage of the structure being learned, therefore calling their attention to the rule. On the other hand, in free practice, tasks such as text creation are presented. The students are given only a topic, that should lead them to use the structure being practiced, but the whole text will be of his authorship. Since the learner would have to pay attention not only to the structure being learned, but the whole text, his use of the rules would be more automatic.

Despite the kind of production practice used, an L2 instructor must be aware of the fact that learners have an inner syllabus, i.e., they acquire some structures before others. Hence, the production practice should not be directed at something the students are not prepared to acquire already, otherwise it will most probably fail. It does not mean that there is a certain level of proficiency that the learners must reach before the teacher starts proposing production practice tasks to them, or whether they should work with controlled or free practices. It only indicates that the teacher has to be cautious in order to use a task that is achievable to his students.

\subsection{Negative Feedback}

When the teacher indicates the students that they have failed to produce a structure correctly, he is giving the student negative feedback. Differently from structured input, 
where the learners are provided with positive evidence, this option offers the students negative evidence. Thus, it is an indication for the student that the utterance he has produced is incorrect, which helps learners notice the gap between his production and the grammatically correct option.

There are several types of negative feedback. The most used are recast, explicit correction, clarification requests, metalinguistic feedback, elicitation and repetition.

Even though the role of negative feedback has been widely discussed among researchers, there still is disagreement over the extent and kind of negative feedback that may be useful in L2 learning. Besides the fact that many teachers and researchers are still not sure of when it is appropriate to correct or give negative feedback to students, studies also indicate the overwhelming tendency of teachers to use recast in spite of the other possibilities of negative feedback (LYSTER \& RANTA, 1997).

For Aljaafreh and Lantolf (1994), the usefulness of negative feedback is extremely dependent on the nature of the transaction and kind of mediation provided by the teacher in this act. On that matter, an interesting study has been conducted by Nassaji and Swain (2000), in which two students of English as L2 from the same level and class were selected. The first learner would receive different types of negative feedback in a scale of options when she produced grammatically incorrect utterances until she could get the mistake and correctly reformulate her sentence - as so to explore her Zone of Proximal Development (VYGOTSKY, 1978). The second one would receive just one different type of negative feedback - selected at random - at each time she produced utterances grammatically incorrect. Independent of whether the student notices the feedback and corrects herself or not, the teacher would continue the conversation with no more prompts. In subsequent sessions, the first student made fewer mistakes than the second student, which indicates that negotiation with different types of negative feedback not only makes sure that the learners notice their flaws, but actually helps them internalize those flaws.

Thus, the most important concern on negative feedback is not to find out which type of feedback would suit each student or each situation best. It is the usage of different feedback options as a way to work with the students' ZPDs that will help them not only notice their mistake, but internalize the rule indeed. 
Another issue regarding feedback is the nomenclature. While some researches use the label negative feedback to indicate this grammar option (ELLIS, 1995; ELLIS, 1998, 1999; LONG, 1977; LONG, INAGAKI and ORTEGA, 1998), others prefer the term corrective feedback (NASSAJI and SWAIN, 2000; LYSTER and RANTA, 1997). Also, some recent researches have been using just feedback (RAUBER and GIL, 2004; CUNHA and LIMA, 2002; KOWAL and SWAIN 1994). The first term could give some people the impression of some kind of disapproval, a pejorative indication of learner failure. This definitely is not the intention behind the grammar option discussed here. Hence it would be preferable to use one of the other two possibilities. Still, some distinction can be made among corrective feedback and feedback.

The term feedback alone can be seen as an umbrella term for any kind of response to a learner's attempt to output. This response may be positive - the so common "very good" of language teachers - or negative - an indication that something may be wrong in the learner's performance. It can also be made by a teacher - who most probably will be certain of the existence of a mistake or error in the student's production - which would be the corrective feedback, or even by a peer - who may not be certain, but at least will think it "sounds strange" and will collaboratively try to negotiate the correct form - what would be a feedback followed by negotiation of form.

Therefore, hereafter the terms corrective feedback or feedback will be used in this article, even when bearing in mind the idea of negative feedback proposed by the computational model of L2 acquisition.

After looking at each instructional option separately, two outcomes can be noticed. The first one is that focus on form is not only one possibility of instruction as a whole, to be distinguished from focus on meaning and focus on use. It is a much more complex form and, consequently, includes sub-options, each of these with their own characteristics and techniques. Secondly, by having in focus on form sub-options that, in turn, have their own sub-options, the number of possibilities to be selected increases exponentially. Consequently, for a researcher or teacher that would want to select from these options the one that would be "his one", the task becomes more and more difficult. But should it really be? Or are we making things even more complex than they already are? 


\section{Why should we select?}

In Ellis (1999), questions like "what kind of form-focused instruction works best?" are indicated to be typically a concern of the teacher's perspective - in contrast to the Applied Linguistics (AL) researcher's perspective. It can be easily confirmed in any daily teaching context. Teachers and language schools are still constantly looking for the perfect formula, and many believe to be holding the answer.

The following situation is an exemplification of this scenario: Once, in a job interview for a language school, the coordinator who was interviewing me showed me the material and presented to me the steps to conduct the class. In every single class there would be the exact same steps for presentation, repetition, indication of grammar topics, practice, production and, if necessary, error correction. I could not help from asking what I should do if, after that, the students still could not understand or use what was being taught. He told me to repeat the same steps. I asked again: "And what happens if they continue not understanding?" His answer was: "With time, they will learn to learn from this methodology". He probably felt that I was going to repeat my question once again, and continued: "But, of course, some students just do not fit our methodology... so they have to go to a different language school."

This not only is a true story, but it seems to be recurrent in many times and places. There are several ESL/EFL ${ }^{3}$ students who narrate to have changed many times from school to school during their "learning journey" in order to find a place where they would fit best - or, at least, where they would be able to adapt themselves enough to fit. But is it the students' task to mold or submit themselves to the school, or should the school be able to provide students with different approaches and ways to help them learn?

Looking back to the computational model (source of figure 1), it is possible to see that the four instructional options are presented together and as elements of a process. It does not impose that the four could only work together. But it certainly indicates that using them in conjunction would improve the quality of the learning process.

\footnotetext{
3 The abbreviations refer, respectively, to English as a Second Language and English as a Foreign Language.
} 
When developing a research or any type of theoretical exposition, if one sticks to one source of evidence or one bibliography reference, the research will be at least tendentious, if not actually poor. In the same way, if a teacher selects only one instructional form or one combination and stick to it forever, would not his practice be tendentious -indicating as "good learners" the ones that fit and as "bad learners" the ones who do not - or actually poor?

The answer may be found in the fact that "typically, grammar lessons are not constructed around a single macro-option, but rather in a combination of options" (Ellis, 1999), but, in researches, it is more common to point out options separately, to indicate the characteristics and effectiveness of each. As a result the teachers - the real users end up selecting one from the options in detriment of the others. Of course it is very difficult to find a grammar lesson that can be taught with only one instructional option. In fact, grammar lessons traditionally start with grammar explanation and then move to production practice, together with feedback. But firstly, believe it or not, there are quite a few lessons based on one macro-option only out there. Secondly, even if we consider that those types of lessons are rare, one cannot say that lessons that involve a certain conjunction of options do not repeat themselves most of the time. The truth is that teachers, schools and methodologies select one instructional option as basis, and then make use of all or some of the others just as reinforcement for the former. Indeed, it is frequently done by using not only the same macro-options but also the same microoptions to support the main option.

With the spread of the PPP - presentation, practice, production - model ${ }^{4}$, one can easily find lessons that involve two or more options. The PPP model is typical of many published language teaching models and of several teachers' lesson plans. This is due to the fact that its logic is appealing to teachers and students, and because it allows the teacher to have control over the pace of the lesson and to deal with unexpected classroom situations (THORNBURY, 1999). On the other hand, the problem concerning the PPP model is that it supposes that language is learned "step-by-step" and amenable under teacher intervention. Also, it delays communication until accuracy is achieved, which might be counterproductive. Therefore, it is not only a matter of the

\footnotetext{
${ }^{4}$ See Larsen-Freeman (1991).
} 
fact that the teacher should not select only one instructional option, because, truth be told, normally they do not select just one. It is a matter, then, of not selecting one sequence of instruction options and sticking to it throughout one's career, as it is commonly seen in many language schools and teachers' methodologies.

An alternative to the PPP model would be the task-based approach, in which the learning cycle would begin from meaning that the learners would want to convey or from tasks they are proposed to. The teacher sets a task, the students try to convey meaning in it, and, from that, the teacher identifies the language features the learners can use for that purpose. At this moment there would be input and/or explicit instruction. Following, the students practice the new structure and perform similar tasks - or even re-perform the previous one - where there will be production practice, and they would receive corrective feedback when errors or mistakes are made.

Yet, neither the PPP model nor the task-based approach will guarantee the success of the class or prevent from demotivation if the educator follows the exact same pattern every single lesson. Consequently, it is still of extreme importance that teachers can be more creative, so their classes do not fall into standard, and principally that they can move through micro-options and even through macro-options whenever it is necessary and that they are able to notice this necessity.

The following task is my suggestion and could be performed by teachers in order to identify to what extend their lessons are falling into a pattern. 
a) Think about the way you usually conduct your grammar lessons. Imagine how you would conduct the presentation, practice, production steps and the eventual correction when teaching a grammar point.

b) Now look at the chart below and see if it matches the scenario represented.

\begin{tabular}{|c|c|c|c|}
\hline Presentation & Practice & Production & Correction \\
\hline -Supplying & -Fill the & - Text & Written: \\
\hline information & banks & creation: & Explicit correction \\
\hline And & & Written: & Or \\
\hline -Explicit & & Write about... & Oral: Recast \\
\hline grammar instruction & & or & \\
\hline & & Oral: Talk to & \\
\hline & & your friend about... & \\
\hline
\end{tabular}

c) Finally, ask yourself how many times you follow these steps and how many times you vary them with others.

Celce Murcia and Hilles (1988), when discussing on whether to teach grammar or not and how to do it, convey that giving students an incomplete grounding in grammar is to do them a great disservice. Their knowledge of grammar will be required and even tested later on, through exams or in everyday use in workplace. Moreover, these tests are probably the main reason why they are studying the language. Hence, the more different experiences the student is provided during his learning the more successful he will be in real life situations. Also, students do best in classes in which the teacher varies the approach in order to accommodate all learning styles; while classes that favor one approach probably will not be equally effective to all students. An eclectic approach would be a better choice to fulfill the class as a whole.

According to the same authors, the grammar lesson consists of four parts: presentation, focused practice, communicative practice, and teacher feedback correction. This is not much different from the PPP model together with the presupposition of corrective feedback whenever necessary. Either ways, the four 
instructional options are to be found in any of the two models' phases. In presentation, students can be exposed to input and receive explicit instruction of the grammar point in discussion. In focused practice and communicative practice, controlled and free practice tasks will be proposed to students, which are the two main micro-options of production practice. And, in teacher feedback correction, corrective feedback will be given to the learners whenever correction is necessary.

As one can see, despite of the different labels given by researchers, the state of art principles of a well-balanced grammar lesson is composed of two main moments. The first is the presentation of the grammar point, when a more passive role will be requested of the learner. And the second moment is the production together with feedback, when the learner will perform a more active role, through tasks where he can use the knowledge learned and check it through the feedback he will receive. This can be represented by the model presented below.

Source of figure 2

A Grammar Lesson Model

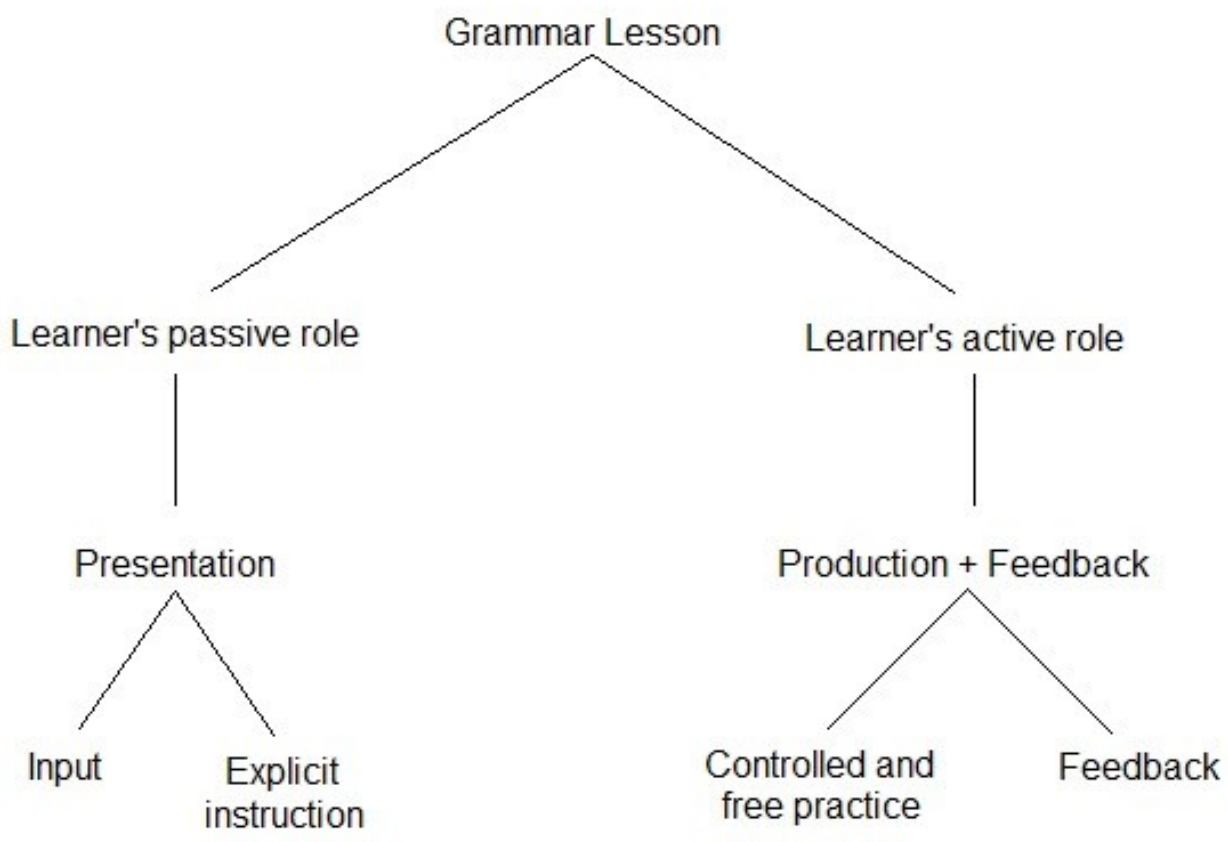


Therefore, success in form-focused instruction relies on a well-balanced use of the four options, instead of on the use of only one of them. Also, there must be balance between the micro-options selected, so not only success is even more increased, but also the lessons become more dynamic and less predictable; which could prevent the students from demotivation.

\section{How to teach, then?}

First of all, it is important to remember that, as mentioned before, the concepts presented by the computational model of L2 acquisition and the instructional options go beyond the concept of method. Consequently, it is not the intention here to present a formula or a perfect ready-to-go lesson. There is no such a thing as a recipe when preparing a lesson, especially when it comes to grammar lessons, for the variables are many. It varies from teacher to teacher, group to group, grammar topic to grammar topic, moment of the lesson to moment, and so on.

It would be interesting, though, to provide learners with a development of the grammar topic throughout the four/macro-options, i.e., starting with structured input, moving to explicit instruction, followed by production practice and, finally, making use of feedback on the student's production. This way, the input-processing conveyed by the computational model would be complete.

Yet, what micro-options for each of these macro-options the teacher is going to select is up to him - or the school, or whoever is responsible for planning the lesson. Still, it would be more intellectually instigating - and less tedious - if these microoptions could vary along the lessons. The student would not know how to solve the tasks in advance, which would make him need to know how to use the structure, and not just put "the new thing" in space without thinking it through. Besides, he would not know in advance when and where the new structures would come, which not only would provide a natural learning, but also would catch his attention for a much longer time, creating a mood for expectation and motivation.

Consequently, it is not a matter of planning just one lesson, but in fact an intention to plan a line of work, constituted of many lessons, a constant work, that will construct the learner's knowledge, and, consequently, develop his interlanguage. The lesson plans 
below were developed throughout my own ELT practice, and exemplify two sequential lessons that make use of different micro-options are presented next, covering the four instructional macro-options.

\begin{tabular}{|c|c|c|}
\hline \multicolumn{3}{|c|}{ Lesson 1} \\
\hline Macro-option & Micro-option & Procedure \\
\hline Structured input & Input enhancement & $\begin{array}{l}\text { - Comparison of sentences; } \\
\text { - Teacher highlights the } \\
\text { linguistic aspect, by using } \\
\text { typological resources. }\end{array}$ \\
\hline Explicit instruction & Direct instruction & $\begin{array}{l}\text { Written explanations of the } \\
\text { grammatical phenomena }\end{array}$ \\
\hline Production practice & $\begin{array}{l}\text { - Controlled practice }- \text { text } \\
\text { manipulation; } \\
\text { - Free practice }- \text { text } \\
\text { creation }\end{array}$ & $\begin{array}{l}\text { - Complete the blanks; } \\
\text { Writing of short } \\
\text { narratives including the } \\
\text { grammar point focused. }\end{array}$ \\
\hline Feedback & $\begin{array}{l}\text { Teacher feedback } \\
\text { Corrective feedback }\end{array}$ & $\begin{array}{l}\text { - Varying between recast, } \\
\text { explicit correction, } \\
\text { clarification requests, } \\
\text { metalinguistic feedback, } \\
\text { elicitation and repetition, } \\
\text { as the teacher judges to be } \\
\text { necessary. }\end{array}$ \\
\hline
\end{tabular}

\section{Lesson 2}

\begin{tabular}{|l|l|l|}
\hline Macro-option & Micro-option & Procedure \\
\hline Structured input & Input flood & $\begin{array}{l}\text { - Use of text, dialogue or } \\
\text { song. } \\
- \text { Teacher supplies info that } \\
\text { leads to the noticing and } \\
\text { understanding of the }\end{array}$ \\
\hline
\end{tabular}




\begin{tabular}{|l|l|l|}
\hline & & structure. \\
\hline Explicit instruction & Indirect instruction & $\begin{array}{l}\text { Consciousness-raising } \\
\text { tasks }\end{array}$ \\
\hline Production practice & $\begin{array}{l}\text { - Controlled practice - text } \\
\text { manipulation; } \\
\text { Free practice - text } \\
\text { creation }\end{array}$ & $\begin{array}{l}\text { Dictogloss; } \\
\text { other some experience } \\
\text { including the grammar } \\
\text { point focused. }\end{array}$ \\
\hline Feedback & $\begin{array}{l}\text { Peer feedback narrate to each } \\
\text { collaborative work }\end{array}$ & Negotiation of form. \\
\hline
\end{tabular}

The examples given do not illustrate the only two possible ways to develop a lesson, so that the next lessons to be planned should not be a repetition of the first two alternately. They should be composed by other different micro-options. Clearly, there would be a moment where the options would end. The teacher can use them again, but favorably in different combinations. He does not even need to wait all the options to cease so that he can come back to one used before. It is profitable to use the same micro-option two lessons ahead, for instance, if it is combined with others when compared to the first pattern in which it showed up.

Of course, it is also possible to use the exact same pattern from a lesson in some other lessons ahead. It is just a matter of not doing it so close to the first time, and trying to make different combinations before repeating it, so the problems concerning anticipation and demotivation mentioned before can be avoided.

\section{Conclusion}

The objective of this article was to present and reflect upon form-focused instructional options for what grammar teaching concerns. Setting the computational model for L2 acquisition as a starting point, it was intended here to discuss if there would be a best way to teach grammar and what it would be. Initially, a presentation of the instructional possibilities was made, where macro and micro-options were pointed out. Next, discussions on the real necessity of selecting one option and on the possibility 
of balancing different options during the same lesson were conducted. Finally, examples of lesson plans with different instructional options were given as a way to illustrate possible grammar-lesson conductions that would follow what was being proposed.

There is not a perfect way or a formula for grammar instruction or for any other aspect of language teaching. The intention behind this article is not to present a solution or impose a way to an effective teaching of form-focused grammar. Instead, the presentation of instructional options and some possibilities of use in classroom aimed at giving suggestions and, most importantly, invoking in teachers the interest to develop their own practice and capacity to alternate their attempts according to context and each particular situation they find themselves into. This constant reflection and search for teaching practice improvement are how grammar - and everything else - can be best taught.

\section{Bibliography}

ALJAAFREH, A., and LANTOLF, J. P. Negative feedback as regulation and second language learning in the zone of proximal development. The Modern Language Journal, n. 78, p. 465-483, dez.1994.

CELCE MURCIA, M. and HILLES, S. Techniques and resources in teaching grammar. New York: Pergamon Press, 1988. 189 p.

CUNHA, A.P. de A. and LIMA, M. dos S. O tratamento de erros orais em sala de aula de inglês como LE. In Marília dos Santos Lima (Ed.) A língua estrangeira em sala de aula: pesquisando o processo e o produto. Porto Alegre: Sagra Luzzato, 2002, p. 928.

DEKEYSER, R. Implicit and explicit learning of L2 grammar: A pilot study. TESOL Quarterly, Boston, n.28, v.1, p. 188-194, jul. 1994.

Learning L2 grammar rules: An experiment with a miniature linguistic system. Studies in second language acquisition, Cambridge, n. 17, v.3, p.379-410, set. 1995.

DEWEY, J. How we think: A restatement of the relation of reflective thinking to the educative process. Boston: Houghton Mifflin Company, 1933. 127 p. 
ELLIS, N. Rules and instances in foreign language learning: Interaction of explicit and implicit knowledge. European journal of cognitive psychology, Leiden, n.3, v.5, p.289-318, mai. 1993.

ELLIS, R. Teaching and research: options in grammar teaching. TESOL Quarterly, Boston, n.32, v.1, p.39-60, jul.1998.

Input-based approaches to teaching grammar: a review of classroomoriented research. Annual Review of Applied Linguistics, Cambridge, n.19, p. 64-80, set.1999.

KOWAL, M. and SWAIN, M. Using collaborative language production and task to promote student's language awareness. Language Awareness. London, n.2, v.3, p.7393, set. 1994.

KUMARAVADIVELU,B. Beyond Methods: Macrostrategies for Language Teaching. New Haven: Yale University Press, 2003. 418 p.

LARSEN-FREEMAN, D. Teaching grammar. In: Celce-Murcia, M. (Ed.). Teaching English as a second or foreign language. $2^{a}$ ed. Boston: Heinle \& Heinle, 1991. 567 p.

LEE, J., and VAN PATTEN, B. Making Communicative Language Teaching Happen. New York: McGraw Hill, 2003. 300 p.

LYSTER, R. \& RANTA, L. Corrective feedback and learner uptake. Studies in Second Language Acquisition, Cambridge, n.19, p. 37-66, jan.1997.

LONG, M. H. Teacher feedback on learner error: mapping cognitions. In: BROWN, H. D., YORIO, C. A., \& CRYMES, R. (eds.), On TESOL '77 Teaching and learning English as a Second Language: Trends in research and practice. Washington D.C.: TESOL, p.278-294, dez. 1977.

LONG, M. H., INAGAKI, S., \& ORTEGA, L. The role of implicit negative feedback in SLA: Models and recasts in Japanese and Spanish. Modern Language Journal, Monterey, n.82, v.3, p.357-371, set. 1998.

NASSAJI, H. and SWAIN, M. A Vygotskian perspective on corrective feedback: The effect of random versus negotiated help on the learning of English articles. Language Awareness, London, n.9, v.1, 34-51, jan. 2000. 
RAUBER, A. S. and GIL, G. Feedback to grammar mistakes in EFL classes: A case study. Revista Brasileira de Linguística Aplicada, Belo Horizonte, n.4, v.1, 2004, p.277-289.

ROBINSON, P. Learning simple and complex second language rules under implicit, incidental, rule-search and instructed conditions. Studies in second language acquisition, Cambridge, n.18, p.27-67, nov.1998.

SPADA, N. Form-focussed instruction and second language acquisition: A review of classroom and laboratory research. Language Teaching, Cambridge, vol.30, 1997, p. 73-87.

THORNBURY, S. How to Teach Grammar. Essex: Pearson Education / Longman, 1999. $182 \mathrm{p}$.

VIDAL, R.T. Ensino-aprendizagem do foco na forma: retorno ou recomeço? The ESPescialist, São Paulo,n.28, v.2, p.159-184, nov. 2007.

VYGOTSKY, L.S. Mind in society: The development of higher psychological processes. Cambridge: Harvard University Press, 1978. 159 p.

Artigo recebido em: 21.03.2012

Artigo aprovado em: 22.05.2012 